Kubiszewska K., The assessment of the situation in banking sectors in selected European countries, „Ekonomia i Prawo. Economics and Law”, Polszakiewicz B., Boehlke J. (ed.), Vol. 15, No. 2/2016, pp. 193-208. DOI: http://dx.doi.org/10.12775/EiP.2016.012.

\title{
THE ASSESSMENT OF THE SITUATION IN BANKING SECTORS IN SELECTED EUROPEAN COUNTRIES
}

\author{
SUMMARY
}

The economic significance of the banking sector is well recognized in the theory and practice. In the literature there are discussed various topics concerning banking: banking sectors stability and its determinants, as well as influence of the banking sector on other sectors of the economy. Moreover the situation in the banking sector has been studied from different perspectives: its stability, profitability, efficiency, competition, concentration. A special part of literature is related to economies in transition. Therefore aim of the article is to conduct a comparative analysis of the financial standing of the banking sectors in selected countries of the Western Balkans, i.e. Bosnia and Herzegovina, Macedonia and Croatia, and current Baltic States (former republics of the USSR), i.e. Lithuania, Latvia and Estonia, few years after the financial crisis. Thanks to the use of the CAMELS method it is possible to check which banking sectors are in better shape: these which are only at the initial stage of transformation of the banking sectors or these where the transformation of this sector has been already completed. The data was collected from International Monetary Fund covering the period of five years 2010-2015, on quarterly basis.

Keywords: CAMELS; banking sector; Western Balkan; Baltic states

JEL Classification: G10; G21; G01

" Katarzyna Kubiszewska, Gdańsk University of Technology, Faculty of Management and Economics, Chair of Economic Analysis and Finance, ul. Narutowicza 11/12, 80-233 Gdańsk, Poland, phone: +48 583472 623, e-mail: kku@zie.pg.gda.pl. 


\section{INTRODUCTION}

The topic of role of banking sector in economy remains one of the crucial in ongoing debate in the literature, especially its stability, profitability, efficiency, competition, concentration. The related researches adopt various methods to verify what is the financial situation of selected banking sectors, with a specially interest to economies in transition. One of such method can be CAMEL which is an early warning system. It is a management system for rating the supervised institutions based on a group of quantitative and qualitative criteria.

The aim of the article is to conduct a comparative analysis, with the use of the CAMELS method, of the financial standing of the banking sectors in selected countries in transition. The chosen countries come from two regions: the Western Balkans, i.e. Bosnia and Herzegovina, Serbia, Macedonia and Croatia, and current Baltic States (former republics of the USSR) i.e. Lithuania, Latvia and Estonia, and to verify the hypothesis weather the impact of the financial crisis was more pronounced in case of countries which are only at the initial stage of transformation of the banking sectors or in case of countries where the transformation of this sector has been already completed. The selected economies experienced vary similar changes in perspective of economy as well political systems, meaning that they had to build the market economy for scratch in parallel to regaining the political and statehood independence.

For this purpose, the article is divided into three sections. In the first one there is conducted a review of literature concerning the study of the financial standing of banking sectors. The second part presents CAMELS method, and the last one verifies the proposed hypothesis by comparing selected financial indicators.

\section{THE IMPORTANCE OF THE ASSESSMENT OF THE SITUATION IN THE BANKING SECTOR}

The importance of the banking sector in the economy cannot be overestimated. The literature concerning banking is very extensive, starting with the explanation of the notion of banking sectors stability, stability determinants, efficiency, profitability, as well as determination of the impact of the banking sector on other sectors of the economy. In the literature there is an ongoing debate on the relationship between the development of the banking sector and economic growth. Some of it favours the thesis of the im- 
portance of finance for the economic growth ${ }^{1}$. Others do not overestimate its impact $^{2}$. For this reason the analysis of the development as well as of the current situation in the banking sector is also confirmed in past studies. The situation in the banking sector is a subject of research from different perspectives: stability $^{3}$, profitability ${ }^{4}$, efficiency ${ }^{5}$, competition ${ }^{6}$, concentration ${ }^{7}$.

For this type of analyses both qualitative as well as quantitative tools are used. One of the simplest measurement techniques is a ratio analysis which is based on financial statements. These measurements are often criticized because of their low information value and a lack of connections with the theory of microeconomics, however, they are most frequently used, mainly due to their simplicity and clarity. More complex techniques of banking sector analysis are based on econometrics and operational research.

1 J.A. Schumpeter, The Theory of Economic Development, Harvard University Press, Cambridge 1934; R.W. Goldsmith, Financial Structure and Development, Yale University Press, New Haven, 1969; R.G. King, R. Levine, Finance and growth: Schumpeter might be right, "Quarterly Journal of Economics", Vol. 108, No. 3, pp. 717-737.

2 J. Robinson, The generalization of the general theory. In The Rate of Interest and Other Essays, MacMillan, London 1952, pp. 69-142; R.E Lucas, On the mechanics of economic development, "Journal of Monetary Economics", Vol. 22, No. 1/1988, pp. 3-42.

${ }^{3}$ J.C.Trichet, Introductory Remarks, [in:] Independence and Accountability Developments in Central Banking, Bank of France 2000; T. Padoa-Schioppa, Reflections on recent financial incidents, Speech given at the Third Joint Central Bank Research Conference on Risk Measurement and Systemic Risk, Basel, 8 March 2002; A. Weber, Financial Market Stability, speech delivered at the London School of Economics, 2008, http://www.bis.org/review/r080610a.pdf 22.04.2016).

${ }^{4}$ S. Mensi, A. Zouari, Efficient Structure versus Market Power: Theories and Empirical Evidence, "International Journal of Economics and Finance", Vol. 2, No. 4/2010, pp. 151-166.

${ }^{5}$ B. Casu., C. Girardone, A Comparative Study of the Cost Efficiency of Italian Banking Conglomerates, "Managerial Finance", Vol. 28, No. 9/2002, pp. 3-23; J.W.B. Bos, H. Schiedel, Comparing Efficiency in European Banking, a Meta Frontier Approach, "De Nederlandsche Bank Research Paper", No. 57/2003; D. Hollo, M. Nagy, Bank Efficiency in the Enlarged European Union, BIS Working Papers, No. 28/2006.

${ }^{6}$ S.I. Greenbaum, A.V. Thakor, Contemporary financial intermediation, Elsevier, London 2007; J.H. Boyd, G. De Nicolò, The Theory of Bank Risk Taking and Competition Revisited, "Journal of Finance", Vol. 60, No. 3/2005, pp. 1329-1343.

7 F. Allen, D. Gale, Financial Contagion, "Journal of Political Economy", Vol. 108, No. 1/2001, pp.1-33; M.K. Sharma., H.K. Bal, Bank Market Concentration: A Case Study of India, "International Review of Business Research Papers", Vol. 6, No. 6/2010. 


\section{CAMELS METHOD AS A TOOL TO ASSESS THE SITUATION IN THE BANKING SECTOR}

\subsection{CAMELS METHOD AS A REASEARCH TOOL}

CAMEL as an early warning system was introduced in the US in the 80s of the $20^{\text {th }}$ century ${ }^{8}$.It is a management system for rating the supervised institutions based on a group of quantitative and qualitative criteria. Their cumulative assessment is a basis for a discussion between the supervising officer and the board of the financial institution and for the informal assessment of its actual situation. CAMELS is an acronym for a group of indicators, by means of which the financial standing of the banking sector is examined. Initially the system evaluated the situation of an institution on the basis of parameters relating to its capital (Capital), quality of assets (Asset quality), management (Management), profitability (Earnings) and liquidity (Liquidity) ${ }^{9}$. Later, after adding the market risk sensitivity (Sensitivity to market risk), it was converted into CAMELS ${ }^{10}$.

\subsection{THE USE OF CAMELS METHOD IN SCIENTIFIC RESEARCH}

The literature abounds with references to CAMELS method. Barket and Holdsworth ${ }^{11}$, confirmed its usefulness using the method to forecast bank failures. Studies supported this proposition, highlighting the importance of the method in the assessment of the situation of a financial institution of the banking sector ${ }^{12}$.

${ }^{8}$ P.W. Bauer et al., Consistency conditions for regulatory analysis of financial institutions: A comparison of frontier efficiency methods, "Journal of Economics and Business", Vol. 50/1998, pp. 85-114.

9 D. Cox, M. Cox, The Mathematics of Banking and Finance, Chichester 2006.

${ }^{10}$ M. Doumpos, C. Zopounidis, A multicriteria decision support system for bank rating, “Decision Support Systems", Vol. 50, No. 2010, pp. 55-63.

${ }_{11}$ D. Barker, D. Holdsworth, The Causes of Bank Failures in the 1980s, "Federal Reserve Bank of New York Research Paper”, No. 9325/1993.

12 R.A. Cole, J. Gunther, Predicting Bank Failures, A Comparison of On-And OffSite Monitoring Systems, "Journal of Financial Services Research", Vol. 13, No. 2/1998, pp. 103-117; R.S. Barr et al., Evaluating the productive efficiency and performance of US commercial banks, "Managerial Finance", Vol. 28, No. 8/2002, p. 19. 
CAMELS method was used by researchers in analyses of specific banking sectors and banks. Said and Saucier ${ }^{13}$ conducted an analysis of banks in Japan. This method was also used in the analysis of the banking sector in India. Prasuna ${ }^{14}$, analysing this banking system for the period of 2003-2004, showed that in the face of strong competition, it is essential for banking institutions to introduce to their offers services better in terms of quality as well as more innovative products. Bhaya ${ }^{15}$ conducted research on selected four private banks. Gupta ${ }^{16}$ in the same way assessed the activity of a group of private banks in the period 2003-2007, while Prasad and Ravidner ${ }^{17}$ assessed the situation of the group of nationalised banks. Mishra and Aspal ${ }^{18}$ conducted an analogous analysis on a group of state-owned banks, providing evidence that despite the differences in the results of each indicator, there is no statistically significant difference in the overall bank rating prepared with the use of CAMEL method.

CAMEL method was applied in the study of Islamic banking in Bangladesh ${ }^{19}$, by means of which the supervisory authority could use Shariah as a benchmark in the inspection and monitoring of Islamic banks. Kabir and Dey ${ }^{20}$ in the same manner analysed activities of private banks in the country. They showed that this method enables improvement of monitoring and control procedures implemented by the supervisors of the banking system.

13 M.J. Said, P. Saucier, Liquidity, Solvency, and Efficiency: An Empirical Analysis of the Japanese Bank's Distress, University of Birmingham $20^{\text {th }}$ Symposium on Banking and Monetary Economics, 2003.

${ }^{14}$ D.G. Prasuna, Performance Snapshot 2003-04, "Chartered Financial Analyst", Vol. 10, No. 11/2004, pp. 6-13.

15 S. Bhayani, Performance of the New Indian Private Banks - A Comparative Study, "Journal of Management Research", Vol. 5, No. 11/2006, pp. 55-59.

${ }^{16}$ R. Gupta, A CAMEL Model Analysis of Private Sector Banks in India, "Journal of Gyan Management", Vol. 2, No. 1/2008, pp. 3-8.

17 K.V.N. Prasad, G. Ravinder, A Camel Model Analysis of Nationalized Banks in India, "International Journal of Trade and Commerce", Vol. 1, No. 1/2012, pp. 23-33.

18 S.K. Mishra, P.K. Aspal, A Camel Model Analysis of State Bank Group, "World Journal of Social Sciences", Vol. 3, No. 4/2013, pp. 36-55.

19 A. Sarker, CAMEL Rating System in the Context of Islamic Banking: A Proposed "S" for Shariah Framework, "Journal of Islamic Economics and Finance", Vol. 1, No.1/2005, pp. 78-84.

20 A. Kabir, S. Dey, Performance Analysis through CAMEL Rating: A Comparative Study of Selected Private Commercial Banks in Bangladesh, "Journal of Politics and Governance", Vol. 1, No. 2/3/2012, pp. 16-25. 
Siva and Natarajan ${ }^{21}$ compared the possibility of the implementation of CAMEL method in the analysis of the results of the SBI banking group. The research shows that systematic analysis with the use of this tool may support a financial institution in the assessment of its financial condition and will act as early warning.

With regard to banking sectors in Europe in the process of transition, Derviz and Podpiera ${ }^{22}$ conducted research comparing the ratings of Standard \& Poor's and those obtained by means of CAMELS method for large banks in the Czech Republic, whose assets accounted for $60 \%$ of the total banking sector. The method also was applied for the analysis of the banking system in Romania ${ }^{23}$ and in Cyprus ${ }^{24}$.

However, this method has not been applied for the analysis of the banking sectors in the countries of the Western Balkans. Therefore, the purpose of this article is to fill this gap in the literature.

\section{THE ASSESSMENT OF THE SITUATION IN BANKING SECTORS IN SELECTED EUROPEAN COUNTRIES}

\subsection{RESEARCH METHODOLOGY}

The object of the evaluation are banking sectors from two groups of countries. The first group constitute countries located in the western part of the Balkans (the former Republic of Yugoslavia), being now in the process of economic transition, also in relation to the banking sector: Croatia, Macedonia and Bosnia and Herzegovina. The second group of countries are Lithuania, Latvia and Estonia. They are examples of countries that in the post-independence phase had to build the foundations of the market economy, including the banking sector, from scratch. Conducting the research on a group

${ }^{21}$ S. Siva, P. Natarajan, CAMEL Rating Scanning (CRS) of SBI Groups, "Journal of Banking Financial Services and Insurance Research", Vol. 1, No. 7/2011, pp. 1-17.

${ }^{22}$ A. Derviz, J. Podpiera, Predicting Bank CAMEL and SEFP Ratings: The Case of the Czech Republic, "Emerging Markets, Finance and Trade", Vol. 44, No. 1/2008, pp. 117-130.

${ }^{23}$ C.T. Albulescu, S.I. Coroiu., Early warning system for the Romanian banking sector: the CAAMPL approach, "The Annals of the University of Oradea. Economic Sciences", Vol. 3, No. 1/2009, pp. 458-466; A. Roman, A. Sargu, Analyzing the Financial Soundness of the Commercial Banks in Romania: An Approach Based on the Camels Framework, "Procedia Economics and Finance", Vol. 6/2013, pp. 703-712.

${ }^{24}$ M. Atikogullari, An Analysis of Norther Cyprus Banking Sector in the Post - 2001 period Through the CAMEL approach, "International Research Journal of Finance and Economics", No. 32/2009, pp. 212-229. 
of countries with a similar historical, economic and political background will ensure the elimination of elements which might disturb thorough comparative analysis.

As it has been already mentioned, CAMEL method was selected for the analysis. Among many indicators of each group there were selected several which describe in the most transparent manner the differences in the development stage of competition of particular banking systems. They are presented in the table 1 .

Table 1. Ratios used in the research according to CAMELS

\begin{tabular}{|c|l|l|}
\hline \multicolumn{2}{|c|}{$\begin{array}{l}\text { REFERRING } \\
\text { PERSPECTIVE }\end{array}$} & \multicolumn{1}{|c|}{ RATIO } \\
\hline C & aspital & $\begin{array}{l}\text { Analysis of capital structure is carried out in relation to assets weighted with risk factors with use } \\
\text { of the following ratios: Regulatory Capital to Risk-Weighted Assets and Regulatory Tier 1 Capital } \\
\text { to Risk-Weighted Assets. }\end{array}$ \\
\hline M & management & $\begin{array}{l}\text { Evaluation of the quality of assets Is delivered in order to estimate the possibility to recover debts } \\
\text { from borrowers: Non-performing Loans to Total Gross Loans. } \\
\text { penses. }\end{array}$ \\
\hline E & earnings & $\begin{array}{l}\text { Maintaining sustainable growth in a banking sector is essential for its operation, development } \\
\text { and credibility. It indicates not only entrepreneurship and effective operation of the management, } \\
\text { but also enhancement of its position in the market of financial services: Return On Assets, Return } \\
\text { on Equity, Interest Margin to Gross Income, Non-interest Expenses to Gross Income. }\end{array}$ \\
\hline L & sensitivity & $\begin{array}{l}\text { Liquidity management is supposed to maintain sufficient cash resources and the proper number } \\
\text { of credit lines, because failure to meet obligations when due causes both clients' and credit insti- } \\
\text { tutions' mistrust, which may lead to bankruptcy, while too high a level results in freezing of a part } \\
\text { of the working capital, and thereby reduces the company's profitability: Liquid Assets Ratio, Liquid } \\
\text { Assets to Short Term Liabilities }\end{array}$ \\
\hline
\end{tabular}

Source: own preparation.

The ratios were collected from International Monetary Fund for period of five years 2010-2015, on quarterly basis.

\subsection{RESULTS OF THE RESEARCH}

Table 2 presents the average ratio values for the selected countries within the period of the analysis. Additionally, the last two rows present the average ratio values for each region separately in order to conduct analysis comparing the regions with each other. 
Table 2. Average values of ratios used in CAMELS method in the studied countries for period Q1 2010-Q1 2015

\begin{tabular}{|c|c|c|c|c|c|c|c|c|c|c|c|}
\hline \multirow{2}{*}{ CounTRY } & \multicolumn{3}{|c|}{ C } & A & M & \multicolumn{5}{|c|}{ E } & \multicolumn{3}{|c|}{ L } & S \\
\cline { 2 - 13 } & $(1)$ & $(2)$ & $(3)$ & $(4)$ & $(5)$ & $(6)$ & $(7)$ & $(8)$ & $(9)$ & $(10)$ & $(11)$ \\
\hline MK & 16.77 & 14.25 & 10.34 & 33.53 & 0.37 & 3.28 & 63.09 & 68.25 & 26.09 & 42.88 & 13.29 \\
\hline HR & 20.19 & 19.03 & 13.47 & 41.70 & 0.98 & 7.06 & 64.87 & 56.82 & 31.94 & 48.85 & 2.28 \\
\hline BA & 16.57 & 13.91 & 12.75 & n.a. & 0.29 & 2.29 & 62.63 & 88.71 & 26.38 & 45.71 & 8.40 \\
\hline LV & 16.81 & 14.26 & 10.40 & 58.30 & 0.37 & 3.17 & 53.34 & 59.39 & 30.70 & 50.03 & 7.50 \\
\hline EE & 23.30 & 21.48 & 3.39 & 42.70 & 1.85 & 14.00 & 51.42 & 49.34 & 18.02 & 24.82 & n.a. \\
\hline LT & 16.54 & 11.11 & 16.69 & 37.89 & 0.56 & 5.15 & 44.64 & 62.78 & 24.16 & 33.67 & 0.51 \\
\hline Balkan States & 17.84 & 15.73 & 12.19 & 37.62 & 0.55 & 4.21 & 63.53 & 71.26 & 28.13 & 45.81 & 7.99 \\
\hline Baltic States & 18.88 & 15.62 & 10.16 & 46.29 & 0.93 & 7.44 & 49.80 & 57.17 & 24.29 & 36.17 & 4.00 \\
\hline
\end{tabular}

Note: MK — Macedonia, HR — Croatia, BA — Bosnia and Herzegovina, LV — Latvia, EE — Estonia, LT — Lithuania,

(1) - Regulatory Capital to Risk-Weighted Assets, (2) - Regulatory Tier 1 Capital to Risk-Weighted Assets,

(3) - Non-performing Loans to Total Gross Loans, (4) - Personnel Expenses to Non-interest Expenses, (5) Return on Assets, (6) - Return on Equity, (7) — Interest Margin to Gross Income, (8) — Non-interest Expenses to Gross Income, (9) — Liquid Assets Ratio, (10) — Liquid Assets to Short Term Liabilities, (11) — Net Open Position in Foreign Exchange to Capital

Source: own preparation based on: International Monetary Fund, IMF elibrary Data, http://data.imf.org (02.09.2015).

The analysis of banking sectors' capital of the countries indicates their very similar situation in this scope. The average capital adequate ratios (CAR) reach very close levels. In each group there is a country where values of CAR are relatively higher. In case of the Balkan States it is Croatia with average of Regulatory Capital to Risk-Weighted Assets Regulatory (figure 1) at the level of $20 \%$ and Estonia — among the Baltic States — with the average of the same ratio over $23 \%$, while in the other countries the ratio does not exceed $17 \%$. The same rule applies to Tier 1 Capital to Risk-Weighted Assets (figure 2), but their values are relatively lower. What shall be stressed is a raising tendency in case of both the ratios. 


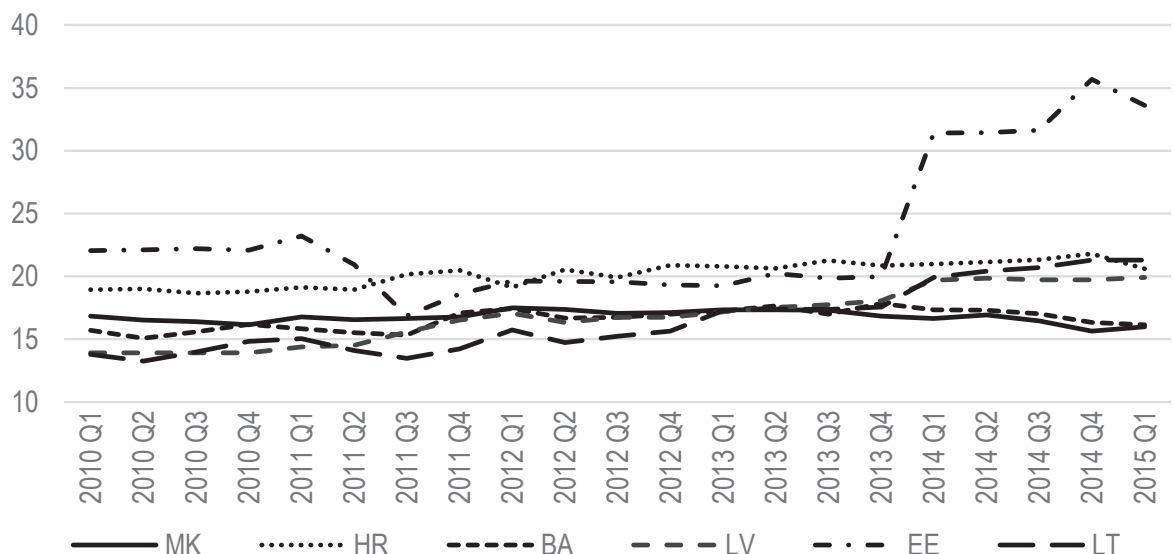

Figure 1. Regulatory Capital to Risk-Weighted Assets (in \%)

Source: own preparation based on: International Monetary Fund, op. cit.

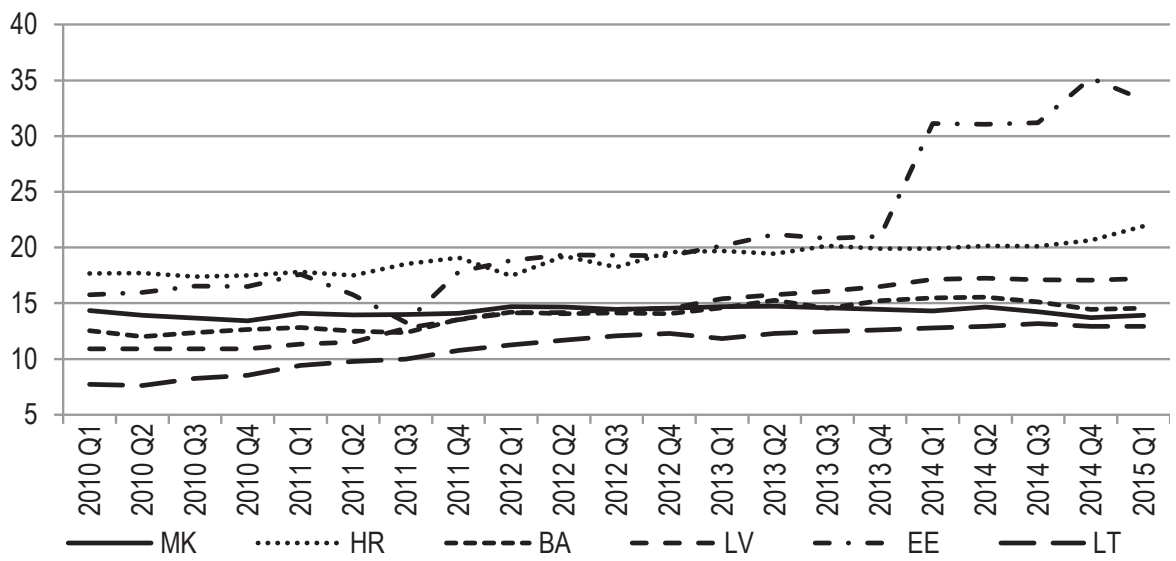

Figure 2. Regulatory Tier 1 Capital to Risk-Weighted Assets (in \%)

Source: own preparation based on: International Monetary Fund, op. cit.

As far as the quality of assets is discussed, it has been noted that the ratio of Non-performing Loans to Total Gross Loans (aka NPL) (figure 3) is decreasing in the Baltic States, while it is increasing in the Balkan States. Moreover, the average value of the ratio in the Baltic States is lower, although at the beginning of the studied period in Latvia and Lithuania their values were significantly higher than in other countries, respectively almost $16 \%$ in Latvia and $24-25 \%$ in Lithuania in 2010. Estonia is the only example where the ratio never exceeded $6.5 \%$ in the analysed period. The situation in this field is relatively worse in the Balkan States. Although the lev- 
el of NPL never exceeded $17 \%$, there is noted a significant raising tendency in all studied countries from this region. The highest ratios were reached in the third quarter of 2014, doubling the values of 2009 in Croatia and Bosnia and Herzegovina. It points out that the economic situation, as the consequence of the global crisis, is not convenient there and may affect the situation of the banking sectors.

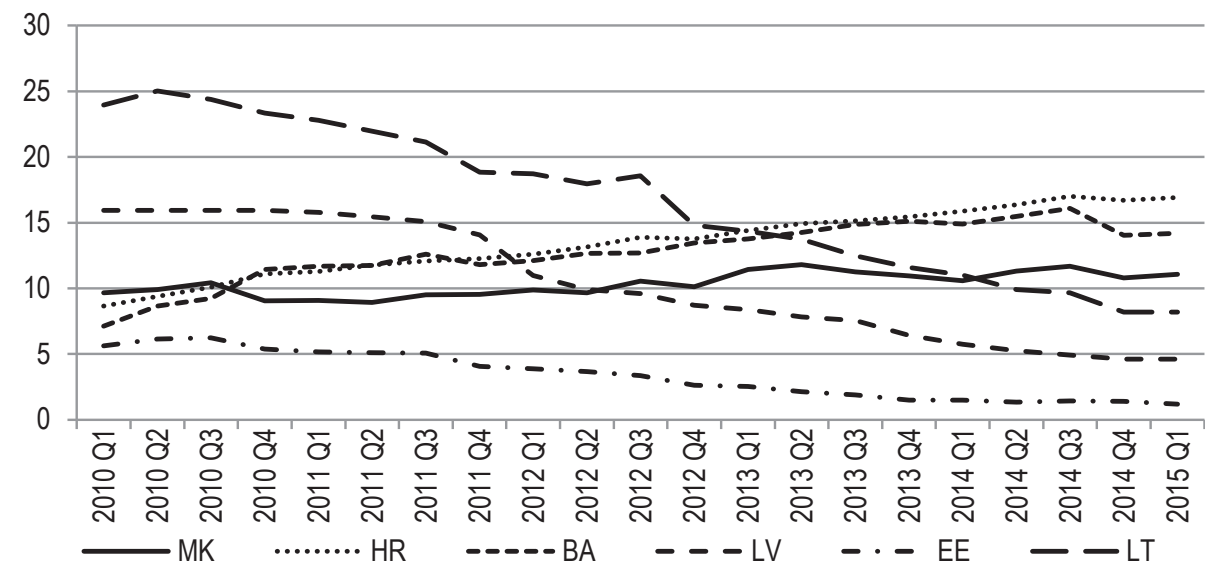

Figure 3. Non-performing Loans to Total Gross Loans (in \%)

Source: own preparation based on: International Monetary Fund, op. cit.

When it comes to management of employees, the ratio of Personnel Expenses to Non-interest Expenses (figure 4) can be used to present the quality and skills of the staff working in the sector. The higher the ratio, the more is spent on employees. Comparing the Balkan and the Baltic States it can be concluded that relatively more (by almost 9 p.p.) is spent in this field in the second group of the countries. Estonia is ranked as the leader in this analysis, because spending on employees there amounts to more than half of the non-interest expenses, increasing from 52\% in Q1 2010 to 67\% in Q4 2014. Macedonia is an example where these expenses not only are the lowest (close to 33\% in Q1 2015) but also present a falling tendency (37\% in Q1 2010). 


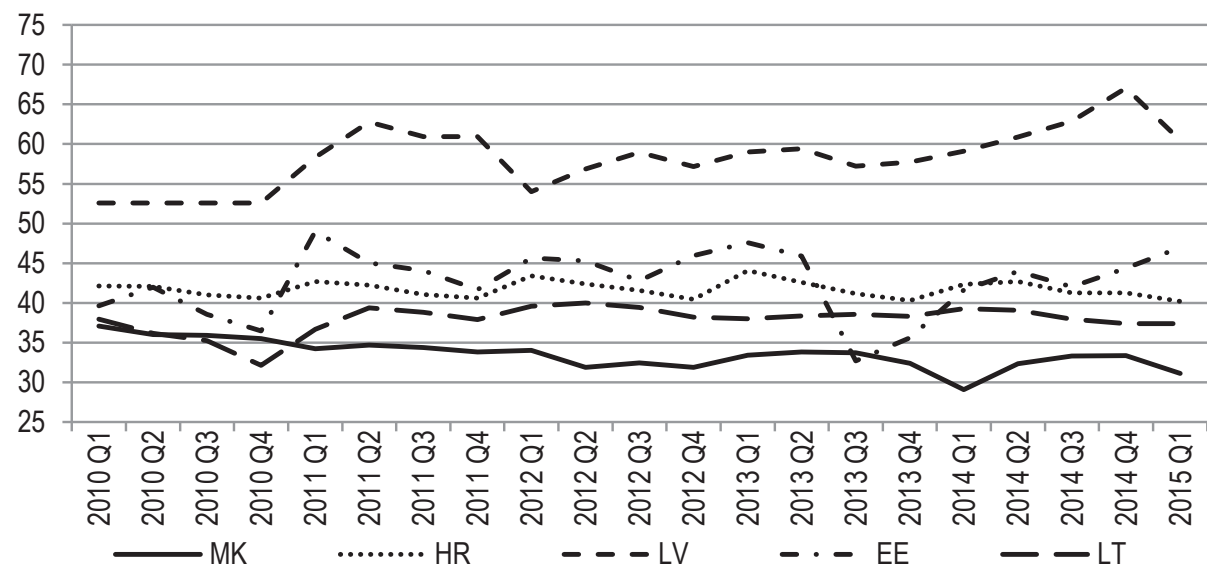

Figure 4. Personnel Expenses to Non-interest Expenses (in \%)

Source: own preparation based on: International Monetary Fund, op. cit.

Comparing performance of the banking sectors in the studied countries, it shall be concluded that better achievements characterise the sectors in the Baltic States. Return on Equity (ROE) and Return on Assets (ROA) ratios (figure 5) present how efficiently the management transfers sources into effects. Both the ratios achieve significantly higher average values in the Baltic States, respectively ROE 7.44\% and ROA 0.93\%, while in the Balkans it is $4.21 \%$ and $0.55 \%$. It shall be mentioned that Latvia is a country which suffered from the global financial crises the most ${ }^{25}$, even comparing to the Balkan States. The performance ratios (ROE, ROA) reached the negative values in 2010 and in Q4 2011. They were also significantly lower than in the other countries. The other two ratios are presented as percentage share of the gross income, which are interest margins (figure 6) and non-interest expenses, achieving higher values in the Balkan States. It can be concluded that in the very competitive European environment of banking sectors, the Baltic sectors managed to diversify their income, relying not only on pure banking activities. The interest margin is explained as the ratio of the net interest income to average assets less the interest due and non-performing loans. The indicator reflects the effectiveness of the banks' income. On one hand, it is the remuneration charged by banks for their services, which is a part of their income. On the other hand, it can be seen as the social cost of the use of the

${ }_{25}$ V. Klyviene, L. Tranberg Rasmussen, Causes of financial Crisis: The Case of Latvia, "Ekonomika", Vol. 89, No. 2/2010, pp. 7-27. 
banking sector. The studies ${ }^{26}$ carried out so far indicate a strong negative relationship between the high value of the margin and the degree of economic growth, so the increase of the ratio corresponds to the decline of efficiency of a sector, and also may be accompanied by lower economic growth.

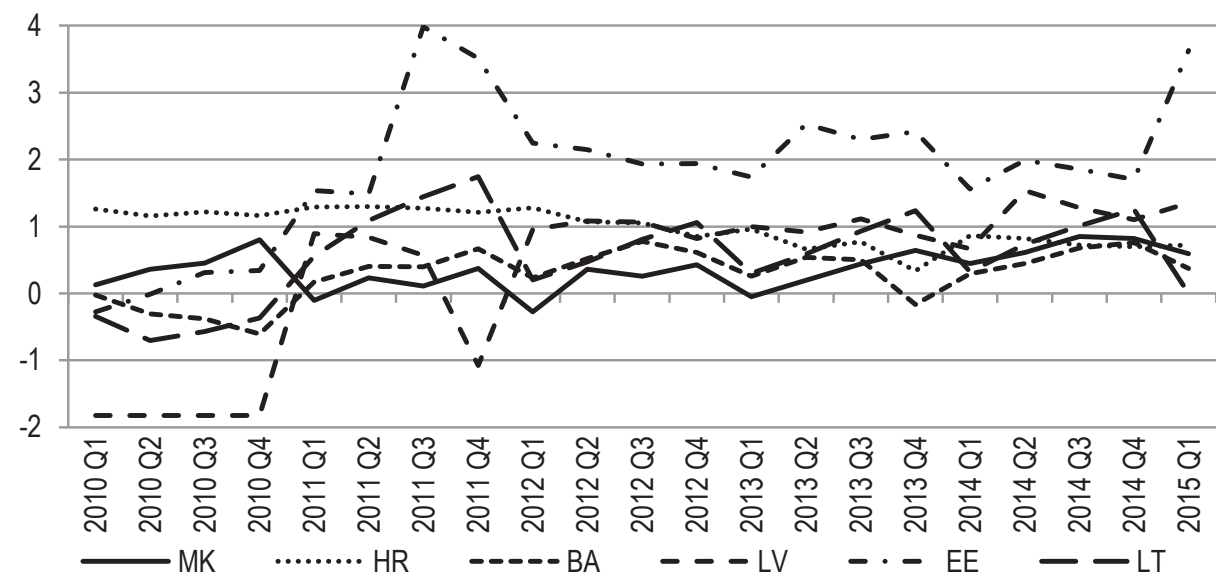

Figure 5. Return on Assets

Source: own preparation based on: International Monetary Fund, op. cit.

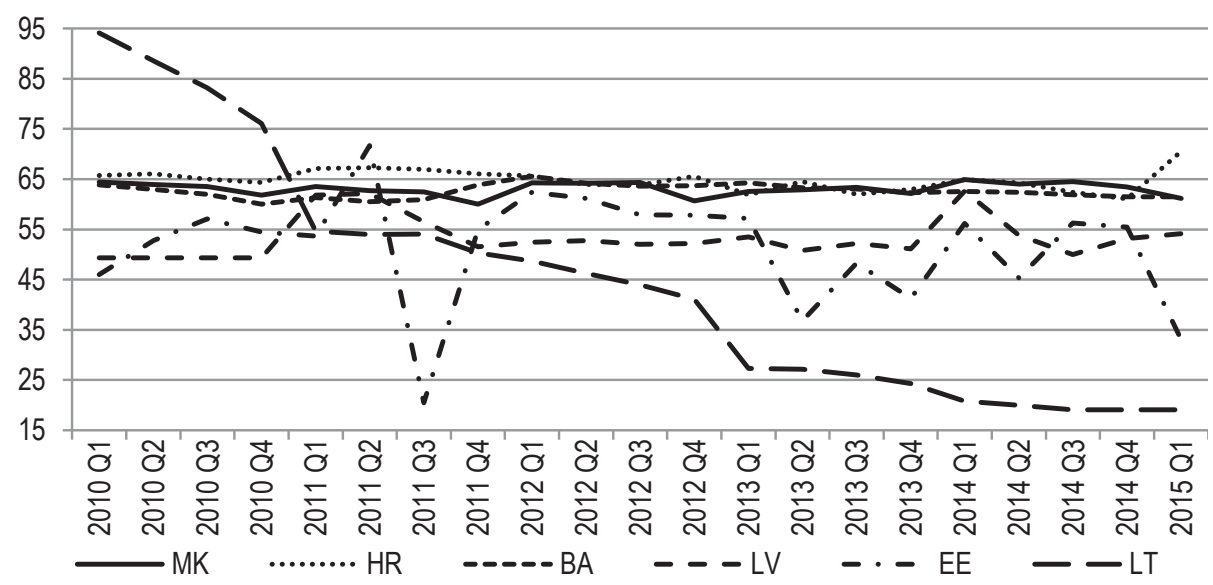

Figure 6. Interest Margin to Gross Income (in \%)

Source: own preparation based on: International Monetary Fund, op. cit.

26 A. Demirgüç-Kunt, L. Laeven, R. Levine, Regulations, Market Structure, Institutions, and the Cost of Financial Intermediation, "Journal of Money, Credit, and Banking", Vol. 36, No. 3b/2004, pp. 593-622. 
Liquidity is one of the most important financial objectives not only of any legal entity, but also of banking sectors analysed as the whole markets. The situation of the compared countries in this scope is rather clear. The Baltic States are characterised by lower liquidity than the Balkan region. The exception here is Latvia, which faced most serious consequences of the global financial crisis, and where the liquidity ratios reach in case of the liquid assets ratio (figure 7) or exceed in case of Liquid Assets to Short Term Liabilities the level of all other countries' ratios.

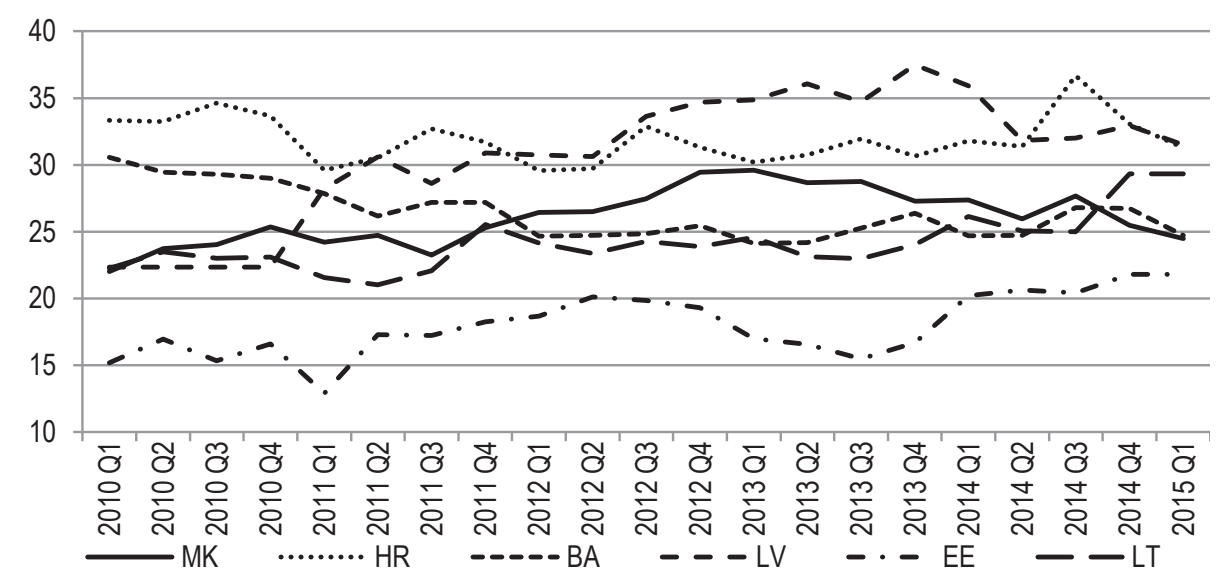

Figure 7. Liquid Assets Ration (in \%)

Source: own preparation based on: International Monetary Fund, op. cit.

The last scope which is crucial is sensibility of the market measured with Net Open Position in Foreign Exchange to Capital (figure 8). The results show that the risk is lower in case of all EU Member States, regardless of the region, the Baltic States and Croatia from the Balkan region. The highest value of the ratio was obtained in Macedonia, which is relatively underdeveloped as far as the banking sector is considered. 


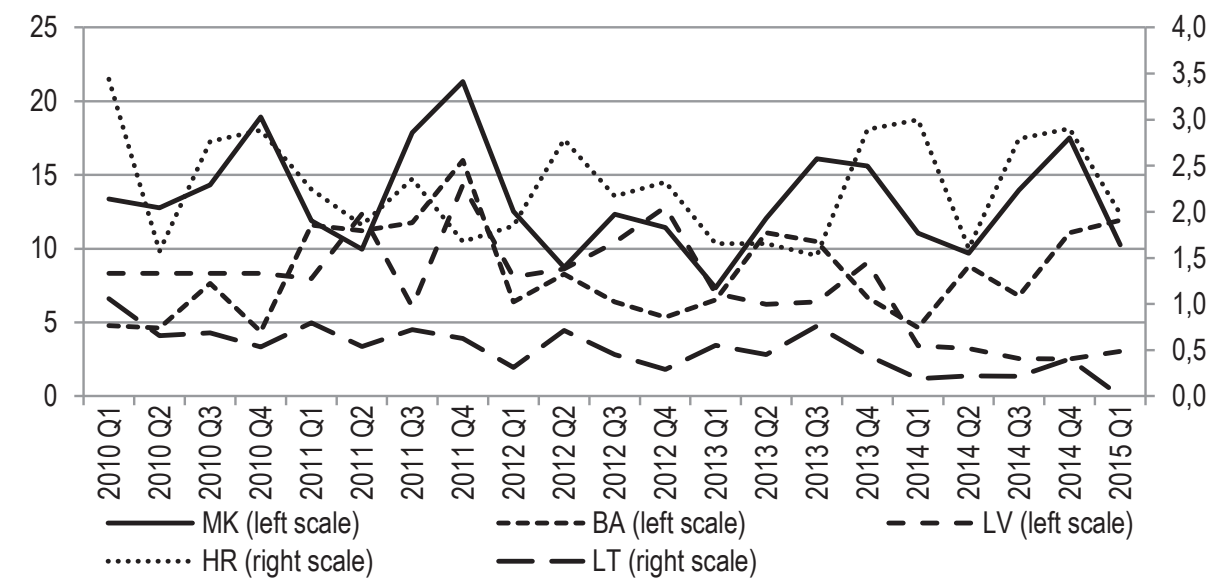

Figure 8. Net Open Position in Foreign Exchange to Capital

Source: own preparation based on: International Monetary Fund, op. cit.

\section{CONCLUSIONS}

Concluding, it shall be stressed that the banking sectors in the Baltic States are overall in a relatively better shape comparing to the Balkan region. It is understandable since the Balkan States started the transformation of their banking sectors much later than the other ones. Both regions suffered from the global financial crisis, which is visible in case of the earning and performance ratios. However, the Baltic States have undergone the recovery much faster which turned out to be very positive for the banking sector.

\section{BIBLIOGRAPHY}

Albulescu C.T., Coroiu S.I., Early warning system for the Romanian banking sector: the CAAMPL approach, "The Annals of the University of Oradea. Economic Sciences", Vol. 3, No. 1/2009.

Allen F., Gale D., Financial Contagion, "Journal of Political Economy", Vol. 108, No. 1/2001, http://dx.doi.org/10.1086/262109,

Atikogullari M., An Analysis of Norther Cyprus Banking Sector in the Post - 2001 period Through the CAMEL approach, "International Research Journal of Finance and Economics", No. 32/2009.

Barker D., Holdsworth D., The Causes of Bank Failures in the 1980s, "Federal Reserve Bank of New York Research Paper”, No. 9325/1993. 
Barr R.S., Killgo K.A., Siems T.F, Zimmel S., Evaluating the productive efficiency and performance of US commercial banks, "Managerial Finance", Vol. 28, No. 8/2002, http://dx.doi.org/10.1108/03074350210767988.

Bauer P.W., Berger A.N., Ferrier G.D., Humphrey D.B., Consistency conditions for regulatory analysis of financial institutions: A comparison of frontier efficiency methods, "Journal of Economics and Business", Vol. 50/1998, http://dx.doi.org/10.1016/ s0148-6195(97)00072-6. p. 85-114.

Bhayani S., Performance of the New Indian Private Banks - A Comparative Study, "Journal of Management Research", Vol. 5, No. 11/2006.

Bos J.W.B., Schiedel H., Comparing Efficiency in European Banking, a Meta Frontier Approach, "De Nederlandsche Bank Research Paper”, No. 57/2003, http://dx.doi. org/10.2139/ssrn.460060.

Boyd J.H., De Nicolò G., The Theory of Bank Risk Taking and Competition Revisited, "Journal of Finance", Vol. 60, No. 3/2005, http://dx.doi.org/10.1111/j.15406261.2005.00763.x.

Casu B., Girardone C., A Comparative Study of the Cost Efficiency of Italian Banking Conglomerates, "Managerial Finance", Vol. 28, No. 9/2002, http://dx.doi. org/10.1108/03074350210768031.

Cole R.A., Gunther J., Predicting Bank Failures, A Comparison of On-And Off-Site Monitoring Systems, "Journal of Financial Services Research", Vol. 13, No. 2/1998, http://dx.doi.org/10.1023/A:1007954718966.

Cox D., Cox M., The Mathematics of Banking and Finance, Chichester 2006, http:// dx.doi.org/10.1002/9781119205920.

Demirgüç-Kunt A., Laeven L., Levine R., Regulations, Market Structure, Institutions, and the Cost of Financial Intermediation, "Journal of Money, Credit, and Banking", Vol. 36, No. 3b/2004, http://dx.doi.org/10.1353/mcb.2004.0045.

Derviz A., Podpiera J., Predicting Bank CAMEL and SESP Ratings: The Case of the Czech Republic, "Emerging Markets, Finance and Trade", Vol. 44, No. 1/2008, http://dx.doi.org/10.2753/ree1540-496x440107.

Doumpos M., Zopounidis C., A multicriteria decision support system for bank rating, "Decision Support Systems", Vol. 50, No. 2010, pp. 55-63, http://dx.doi. org/10.1016/j.dss.2010.07.002.

Goldsmith R.W., Financial Structure and Development, Yale University Press, New Haven, 1969.

Greenbaum S.I., Thakor A.V., Contemporary financial intermediation, Elsevier, London 2007.

Gupta R., A CAMEL Model Analysis of Private Sector Banks in India, "Journal of Gyan Management", Vol. 2, No. 1/2008.

Hollo D., M. Nagy, Bank Efficiency in the Enlarged European Union, BIS Working Papers, No. 28/2006.

International Monetary Fund, IMF eLibrary Data, http://data.imf.org (02.09.2015). 
Kabir A., Dey S., Performance Analysis through CAMEL Rating: A Comparative Study of Selected Private Commercial Banks in Bangladesh, "Journal of Politics and Governance", Vol. 1, No. 2/3/2012.

King R.G, Levine R., Finance and growth: Schumpeter might be right, "Quarterly Journal of Economics", Vol. 108, No. 3, http://dx.doi.org/10.2307/2118406.

Klyvienè V., Tranberg Rasmussen L., Causes of financial Crisis: The Case of Latvia, "Ekonomika", Vol. 89, No. 2/2010.

Lucas R.E., On the mechanics of economic development, "Journal of Monetary Economics", Vol. 22, No. 1/1988, http://dx.doi.org/10.1016/0304-3932(88)90168-7.

Mensi S., Zouari A., Efficient Structure versus Market Power: Theories and Empirical Evidence, "International Journal of Economics and Finance", Vol. 2, No. 4/2010, http://dx.doi.org/10.5539/ijef.v2n4p151.

Mishra S.K., Aspal P.K., A Camel Model Analysis of State Bank Group, "World Journal of Social Sciences", Vol. 3, No. 4/2013, http://dx.doi.org/10.2139/ssrn.2177081.

Padoa-Schioppa T., Reflections on recent financial incidents, Speech given at the Third Joint Central Bank Research Conference on Risk Measurement and Systemic Risk, Basel, 8 March 2002.

Prasad K.V.N, Ravinder G., A Camel Model Analysis of Nationalized Banks in India, "International Journal of Trade and Commerce", Vol. 1, No. 1/2012.

Prasuna D.G., Performance Snapshot 2003-04, "Chartered Financial Analyst", Vol. 10, No. 11/2004.

Robinson J., The generalization of the general theory. In The Rate of Interest and Other Essays, MacMillan, London 1952.

Roman A., Sargu A., Analyzing the Financial Soundness of the Commercial Banks in Romania: An Approach Based on the Camels Framerwork, "Procedia Economics and Finance”, Vol. 6/2013, http://dx.doi.org/10.1016/s2212-5671(13)00192-5.

Said M-J. B., Saucier P., Liquidity, Solvency, and Efficiency: An Empirical Analysis of the Japanese Bank's Distress, University of Birmingham $20^{\text {th }}$ Symposium on Banking and Monetary Economics, 2003.

Sarker A., CAMEL Rating System in the Context of Islamic Banking: A Proposed "S" for Shariah Framework, "Journal of Islamic Economics and Finance", Vol. 1, No.1/2005.

Schumpeter J.A., The Theory of Economic Development, Harvard University Press, Cambridge 1934.

Sharma M.K., Bal H.K., Bank Market Concentration: A Case Study of India, "International Review of Business Research Papers", Vol. 6, No. 6/2010.

Siva S., Natarajan P., CAMEL Rating Scanning (CRS) of SBI Groups, "Journal of Banking Financial Services and Insurance Research”, Vol. 1, No. 7/2011.

Trichet J.C., Introductory Remarks, [in:] Independence and Accountability Developments in Central Banking, Bank of France 2000.

Weber A., Financial Market Stability, speech delivered at the London School of Economics, 2008, http://www.bis.org/review/r080610a.pdf (22.04.2016). 